\title{
IS IT A SMART CITY A CREATIVE PLACE?
}

\author{
Emilian GWIAŹDZIŃSKI (1) ${ }^{1, *}$, Dominika KACZOROWSKA-SPYCHALSKA ${ }^{2}$, \\ Luís MOREIRA PINTO ${ }^{3,4}$
}

\author{
1, 2 University of Łódź, Faculty of Management, Department of Marketing \\ 22/26 Matejki str., 90-237 Lodz, Poland \\ ${ }^{3}$ University of Beira Interior, Faculty of Architecture, Department of Civil Engineering and Architecture, \\ Calçada Fonte do Lameiro, 6201-001 Covilhã, Portugal \\ ${ }^{4}$ CITAD Research Center, Rua da Junqueira, 188-198, 1349-001, Lisbon, Portugal
}

Received 27 January 2020; accepted 1 July 2020

\begin{abstract}
Along this article we share our research in the field of urban creativity, in particular on how smart cities are becoming more and more independent and developing a spirit of sustainable autonomy that somehow creates creative opportunities in terms of memory and cultural identity. Our current article raises the issue of how can smart cities affect the creative process? We believe that creativity becomes a process linked into a digital world and becomes much more interactive. That is why new ways of artistic and digital expression can be welcomed by those who are used to new technologies, which daily influence human activity in the space of the city. In other words, with the use of the existing technology inside the cities and their interconnections with other cities we can conceive creative strategies that will contribute to preserve the memory as well as the cultural and creative identity of a people. Video-mapping is precisely one of those creative strategies, once it will directly interact between the real dimension and the virtual dimension. The use of video-mapping, as an element of covering the facades of buildings, can somehow help to make the streets more dynamic and transform them into other atmospheres. The city becomes part of the third dimension and people are interacting between the real and the virtual. The management of the urban space has been gradually changing and following the technological advance. Mobility and sustainability is one of the key factors in which a smart city has invested the most. Now is the time to invest in a relationship between the city and the people, making it more humane and giving space for creativity.
\end{abstract}

Keywords: creative city, digital technologies, human being, information and communications technologies, management, smart city.

\section{Introduction}

The cities are becoming more and more attractive to people seeking safety, work, stability and some comfort in mobility. In urban areas we can find commercial and business activities, but we also can find public buildings with specific departments, such as political organizations, schools, hospitals and many other facilities. But there is one resource which, across time,

${ }^{*}$ Corresponding author. E-mail: emilian.gwiazdzinski@uni.lodz.pl 
has been revealed as a form of urban cultural expression, namely their buildings and all the urban design which reveals the evolution of the city and the historical past. In a city we can read and understand the cultural identity of a population.

Nowadays cities are also a key element in the world of tourism, as they are increasingly attracting visitors from all over the world seeking out other cultures and customs.

The city is a stage where people, objects and places are the creative background for a structural narrative which through their connections and actions will reveal another invisible side of the dimension of the city, we mean the intangible and interconnected dimensions that are part of collective narrative. Architecture emerges as a key element that links tradition and culture, is a kind of reflection of the city itself and people who lives in the city.

With technological advance, and the use of nanotechnology, surfacing and building materials have emerged capable of solving technical and constructive problems and the same time addressing some of the issues related to façade surfacing materials.

Now we live in cities full of sensors, some to regulate car traffic, others to regulate the time to turn on the street lights, others to identify people's faces because of security issues, others simply check the car plates at the entrance or exit of a car parking area. Anyway, how can we be creative? How can the city contribute to influence the cultural creativity of a set of people? How can the city attract more people to a particular place, stimulate commerce and attract tourists?

\section{Literature review}

The literature review concerning a substantive basis for the characteristics of smart city phenomenon was prepared based on scientific bases: Scopus and Web of Science (Table 1).

The first stage of literature exploration was to define areas, among which search phrases appeared. It was decided that they are to include: a title of article, abstract and keywords. Then, due to a large number of records after putting a "smart city" phrase, the authors included also a "perception" phrase. Another stage aimed to narrow search results only to articles of research and review nature. The result was the total of 156 records, in which articles from Scopus base (over $76 \%$ of records) were significant prevalence. The next selection criterion was accessibility, in both bases there were altogether 58 articles at open access. The last stage aimed to verify papers in terms of appearance in both bases (duplicates of articles were removed). Altogether there were 48 articles meeting the abovementioned selection criteria.

Table 1. Literature review for selected frases (source: created by authors)

\begin{tabular}{|l|c|c|}
\hline \multirow{2}{*}{ Selection criteria } & \multicolumn{2}{c|}{ Number of records for repository } \\
\cline { 2 - 3 } & Scopus & Web of Science \\
\hline "Smart city" - title, abstract and keywords & 53102 & 6480 \\
\hline "Smart city" AND "perception" - title, abstract and keywords & 373 & 82 \\
\hline Articles of research nature and literature reviews & 119 & 37 \\
\hline Articles at open access & 42 & 16 \\
\hline Total number of articles after removing duplicates & \multicolumn{2}{|c|}{48} \\
\hline
\end{tabular}


In the analyzed publications, in the context of perception of smart city, a smart paradigm was often described as it combined such information technology elements as information and communications technologies (ICT) with urban space, houses or even the community (Uzzell, 2008; Anilir et al., 2009; James \& Nagasaka, 2011; J.-H. Lee \& W.-J. Lee, 2013; Kim et al., 2014). Smart city was also described in the context of e-community, development of education thanks to ICT (Cheng et al., 2015) and public health (Muhajarine et al., 2015). The development of community towards e-community, referred to as information society or network society, focuses on using technologies and the Internet to support everyday life e.g. to facilitate public health care through electronic booking, using electronic cards of patients or remote consultation with a doctor and conducting some measurements at home by means of special sensors, e.g. heartbeat, pressure or pulse. On the other hand, after 2015 the concept of smart city started to be perceived in a holistic way and some focus was put on the context of management model using ICT (Musatova et al., 2016; Niaros, 2016) along with sensors and the Internet of things (IoT) (Li \& Zheng, 2016; Pérez et al., 2016). Technology and sensors have become an important pillar of a model of city and community management. Already in 2017 there were remarks about intelligent urban infrastructure illustrated by the case of intelligent transportation system, which will enable to use existing road networks both in public or private transport more economically by means of visual sensors (Leone et al., 2017; Ruutu et al., 2017; Stanković et al., 2017). Such sensors allow to analyze individual road phenomena such as rush hours or level of congestion in order to optimize transport management or parking systems in the most efficient way. Ruutu, Casey and Kotovirta (2017) also mentioned introduction of special digital platforms which, beside supporting city management, can facilitate a flow of information between city administrative bodies and business sectors to manage resources in a better and more efficient way. In turn, Bhati, Hansen, and Chan (2017) described a concept of electric energy management in urban space. Thanks to sensors and data analysis one can design a system of management, monitoring, planning and energy optimization so that comfortable and safe environment could be created both at a municipal level as well as houses and other housing spaces. In later years, a concept of smart city was perceived in an aspect of sustainable and creative city (Niculescu-Dincă, 2018) in social-cultural space (Chan \& Marafa, 2018). These elements contribute to building a city brand and increase its competitiveness in relation to other cities. Sustainable city, otherwise referred to as green city, assumes in its strategy taking care of such elements as air and water quality (e.g. by taking care of $\mathrm{CO} 2$ level reduction), green areas such as parks, waste management, public transport (Bell et al., 2018), energy (Pan \& Cheng, 2018), quality of residents' life (Chan \& Marafa, 2018; Calderón et al., 2018; D’Aniello et al., 2018) (e.g. taking care of health (Ek et al., 2018)) and sound environment (Kang et al., 2018) which influences the comfort of life of urban community. According to Chen and Lin (2019) smart city architecture takes into account 20 areas including in particular information infrastructure based on ICT, artificial intelligence, the IoT or solutions based on a cloud and fog computing (Du et al., 2019; Lytras et al., 2019; Milošević et al., 2019; Sánchez-Teba \& Bermúdez-González, 2019), e-administration, social insurance, intelligent transportation (Suryanegara et al., 2019), e.g. electric and autonomous cars (Si Min Lim \& Taeihagh, 2019), intelligent diagnosis and treatment as well as video-mapping (Yang, 2019). 
The review of literature indicates similarities and differences in the perception of a smart city concept. The table below (Table 2) presents definitions of a smart city concept that appear in the analyzed literature.

Table 2. Review of definitions of smart city concept found in the analyzed publications (source: created by authors)

\begin{tabular}{|c|c|c|}
\hline Year & Definition & Source \\
\hline 2014 & $\begin{array}{l}\text { Defined as smart spaces occupied by smart community } \\
\text { that "emphasizes interactive participation of residents, } \\
\text { extending the use of technology beyond home automa- } \\
\text { tion. With advances in information communication tech- } \\
\text { nologies (ICTs) people have been freed from constraints } \\
\text { of place, thus physical proximity is becoming less essential } \\
\text { to communication". }\end{array}$ & $\begin{array}{l}\text { Kim et al. (2014, pp. 539- } \\
540)\end{array}$ \\
\hline 2015 & $\begin{array}{l}\text { "[...] can be broadly defined as the diffusion of urban } \\
\text { public services through the use of information technology } \\
\text { to provide convenience to businesses and citizens". }\end{array}$ & Cheng et al. (2015, p. 21) \\
\hline 2016 & $\begin{array}{l}\text { "[...] the 'smart city' idea has crystallized into an image of } \\
\text { a technology-led urban utopia permeated with top-down } \\
\text { and centrally controlled technological infrastructures, } \\
\text { with the aim to improve the urban environment in terms } \\
\text { of efficiency, security and sustainability". }\end{array}$ & Niaros (2016, p. 51) \\
\hline 2017 & $\begin{array}{l}\text { "The concept comprises creative and innovative } \\
\text { solutions based on harnessing technologies in various } \\
\text { aspects of urban living, integrating its economic, social, } \\
\text { environmental and governmental dimensions. It is seen } \\
\text { as a holistic process of redesigning urban areas, aimed } \\
\text { at achieving sustainable urban growth, efficient service } \\
\text { systems and increasing the citizens' quality of life". }\end{array}$ & Stanković et al. (2017, p. 520) \\
\hline 2018 & $\begin{array}{l}\text { "[...] are indeed capable of collecting, processing and pro- } \\
\text { viding feedback on data coming from multiple networks } \\
\text { at different scales, in order to promote sustainability and } \\
\text { improve people's quality of life. [...] Furthermore, it has } \\
\text { also been noted that the concept of smart cities is not only } \\
\text { focused on technological aspects, and is gradually evolv- } \\
\text { ing into a broader idea including components strongly } \\
\text { connected to people and community". }\end{array}$ & Kang et al. $(2018$, p. 46$)$ \\
\hline 2018 & $\begin{array}{l}\text { "[...] a city would be considered 'smart' if it applies ICT } \\
\text { based solutions to problems in these six dimensions: } \\
\text { governance, quality of life and essential services, } \\
\text { transportation (mobility), economy, people, and } \\
\text { environmental issues. Furthermore, a city must include } \\
\text { initiatives and projects in their development plans to be } \\
\text { considered as a city becoming smart". }\end{array}$ & Calderón et al. (2018) \\
\hline 2019 & $\begin{array}{l}\text { "A more complete definition is that a smart city is a place } \\
\text { where information and communication technology (ICT) } \\
\text { is combined with infrastructure, architecture, common } \\
\text { objects and our government bodies to deal with social, } \\
\text { economic and environmental problems". }\end{array}$ & $\begin{array}{l}\text { Contreras Pinochet et al. } \\
(2019, \text { p. } 74)\end{array}$ \\
\hline
\end{tabular}




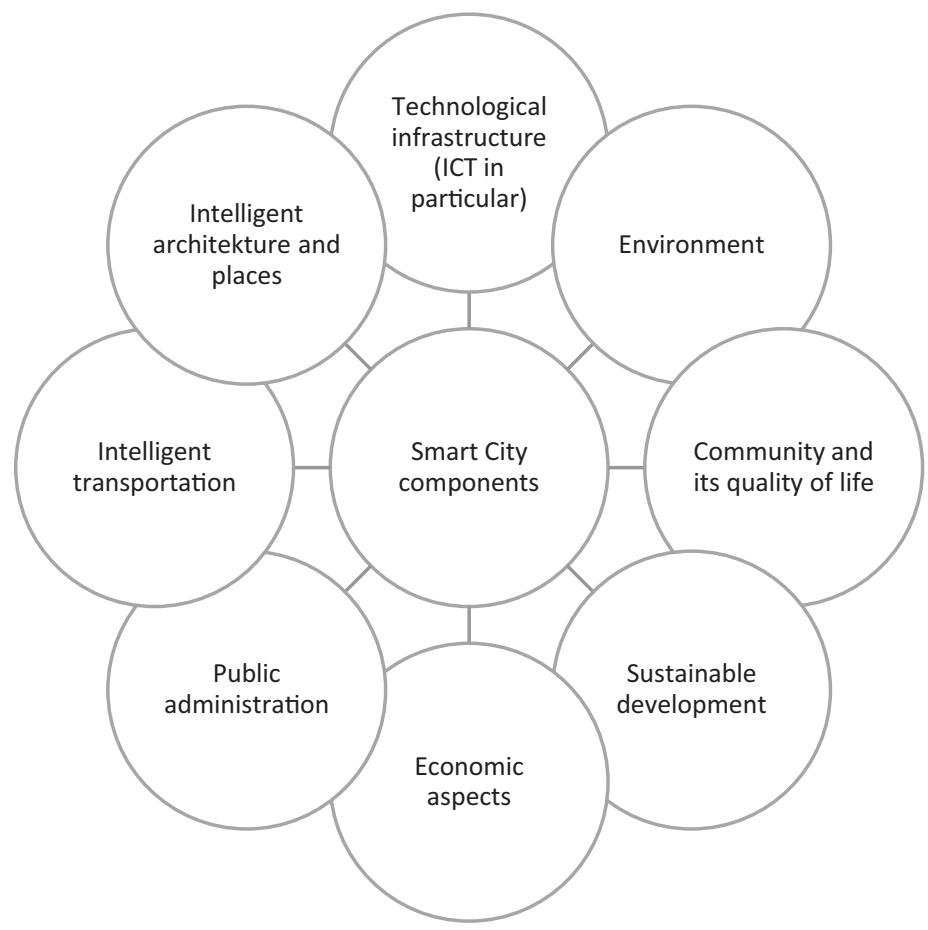

Figure 1. Diagram of smart city components based on the abovementioned definitions (source: created by authors)

Having compared the above definitions and after conducting their synthesis, the following components of smart city can be specified (see Figure 1).

The above components of the diagram are foundations of functioning of the smart city concept. Each of them is an integral element of interaction of the whole smart urban ecosystem.

Recently, a certain foundation of smart city activity has also been mentioned more and more often - the 5th generation network. It is a network operating in higher frequency bands reducing the latency period to 1 millisecond (for 3G network this period was 300 milliseconds, for $4 \mathrm{G}$ - 30 milliseconds). This network also provides more capacity, enabling the deployment of fully autonomous urban vehicle infrastructure such as autonomous buses, autonomous trains, autonomous taxis or autonomous trams.

\section{Smart city: technology versus human}

The global smart city market is moving into a period of maturity, with a growing number of comprehensive smart city strategies and commercial projects. The past year has seen significant growth in smart city solutions that integrate data and insights across multiple operations and service sectors (Guidehouse Insights, 2019). Digital technologies such as the IoT, artificial intelligence, big data or augmented reality are perceived both as a new dimension of urban space and philosophy of its management. Smart cities hold the promise to potentially 
make the growing number of cities around the globe more efficient, more tech-savvy, more wired and with all that, they can hopefully improve the quality of life for citizens (Reardon, 2016). They are about productivity gains through automation and algorithmic analysis and about economic growth. According to IBM, smart cities are an "interconnected, instrumented and intelligent" areas (Casile, 2011).

Technologies become ubiquitous (so-called general purpose technology) in urban space and their usage enables to collect and analyze big amounts of data leading to optimization of the process of urban management. Intelligent algorithms start to become a kind of the city nervous system, so-called automated decision-making (Algorithm Watch, Bertelsmann Stiftung, 2019), facilitating modification of undertaken decisions often in real time. Based on technological innovations, smart cities are complex ecosystems that have an integrated analysis approach that considers the smart city as an organic whole (Macke et al., 2018). However, technology as an only determinant of smart city idea (technological determinism) leads to identification of a social dimension with technological dimension in urban space. As such, technology becomes an autonomous and self-determined structure controlling society development, its directions and dynamics, including smart city identity (Reddy Kummitha \& Crutzen, 2017).

But a technological paradigm is only a way of "perception" of a limited set of possible technological alternatives and of a notional future development (Dosi, 2000, p. 52). A city is not a computer and the urban intelligence is more than information processing (Mattern, p. 2017). Moreover, technological paradigms can develop that are not conducive to social welfare, and once set up, their internal structure makes them difficult to change (Tunzelmann et al., 2008, p. 477). It also results in excessive city reliance directly on technologies and based solutions as well as on corporations from ICT sector which create, sell and represent these technologies (Kunzmann, 2014). Then, smart city serves mostly their interests, marginalizing a role and needs of local communities. Moreover, the algorithmic logic for automation and optimization that guides smart city solutions is not enough for delivering the full potential (Komninos \& Kakderi, 2019, p. 2) of them.

So, perception of smart city only in categories of technology-based city, definitely depletes its ideas and limits future possibilities of its development.

For this reason, truly smart city starts from the human capital side, rather than blindly believing that only technology can automatically create "a smart city" (Hemalata et al., 2019). It should be an integrated system in which human and social capital interact, using technology based solutions (Monzon, 2016). It requires then transferring a weight from technology to a human who thanks to creativity and engagement will not only notice symptoms of its implementation and related intelligent algorithms in urban space, but will be able to create, modify and enrich them. They will become a part of their life in which a human will decide to what extent they will be used and to what extent they will allow for higher psychological and socio-cultural awareness (Zandbergen, 2011). Thanks to that, technology will become a tool enabling to manifest their thoughts and dreams (Wuebben, 2017, p. 123).

"Smartness" is not just installing digital interfaces in traditional infrastructure or streamlining city operations. It is about using technology and data purposefully to make better decisions (McKinsey Global Institute, 2018). 
A human and his creativity must become a key element of city intelligence DNA - their distinctive feature. Interactions between technology and a human are of dual nature - society is a dimension of technology and technology is a dimension of society (a double helix of human-technology interaction). The number and diversity of stakeholders, companies, organizations, and institutions involved, together with the requirements of infrastructure deployment in all the dimensions of the city smartness, and the need for integration of all these systems and agents, while making these systems accessible for all (inclusive), are probably the main challenges that the vision of smart cities will face in the forthcoming years (Moura \& Abreu e Silva, 2019). Based on creativity capital of its participants they become a kind of continuum of their existence (creative city where creativity is a key to create a smart city and a humane city - using human capital to build social infrastructure) (Nam \& Pardo, 2011).

Technological changes are then of secondary nature and are conditioned by social needs. What is more, smart society is able to free a potential of technology while determining its way of absorption, its implications and creation of new based solutions. A way of absorption of any technology cannot be realized without understating its consequences in a sociocultural, behavioural or economic dimension.

The challenges of tomorrow's city demand new ways of thinking, for this reason, smart city needs three constitutive elements: smart technology, smart people and smart collaboration between them (Meijer \& Rodríguez Bolívar, 2015). It should be a one that combines best a two worlds; on the one hand, a social city that is people-centered, values active citizenship and community-driven creative innovation, and, on the other, a smart city that welcomes the possibility of technology (Mulder, 2014). It results in metamorphosis of our surrounding reality - from virtual to ubiquitous, from smart to adaptive, becoming a subsequent stage of evolution of cities from a technology-intensive to a creative-intensive smart urbanism.

\section{Cultural memory and the use of video mapping technology}

Throughout time many definitions have been given about what a city is and how it is perceived. A mosaic of social worlds (Wirth, 1938) or, for example, also defined as a geographical network, an economic organization, a theatre of social action and an aesthetic symbol of a collective unity when referring to architecture (Mumford, 1937).

The city of today does not exist because the city of today is the city of the future, the city lives between the past and the future between a collective memory and an historical memory. The city landscape is in continuous metamorphosis. The city landscape is being reinvented, the urban layout of the city is now addicted to the technology, ecology and sustainability.

There is no such thing as a city if there is no architecture or architectural objects. They reflect the culture and the historical moment in which the city was built. That is why the urban space has been organized in a way which includes several features linked with what we nowadays classify as a creative city. Creativity as a background has been closely related with the concept of creative city, contemporary urban planning and architectural narratives (Rabazauskaite, 2015). The way in which we see the city, the sensations and emotions that are transmitted, to each of us, as we walk along the streets, are a kind of fuel to feed the individual perception of the urban landscape. 
The urban landscape links the sensorial perception to the passage of time. We can feel the complexity of colours and shadows, which are living in harmony with the shapes of the constructed landscape, with the reliefs and textures (Holl et al., 2006). This is a sensorial experience, often associated to the creativity, to observe a city in loco or to remember the city by the memories that were registered in our mind.

Before the industrial revolution, buildings had very ornamented facades, which reflected in some way an aristocratic or bourgeois taste, that mirrored the social life and their importance in the urban context of those times. But after the industrial revolution, the internal design of houses became more important. The way in which the house was structured inside rather than the façades which turned to be simpler and less ornamented.

Nowadays architecture is almost like a big object of design, there is a very powerful identity which usually marks a place in the city itself, turning the building almost like an icon, attracting many people to the spot, both for its function and for its layout.

The architect became more creative and freer of artistic influences and styles, which were considered beautiful and should therefore be followed. The buildings are now more abstract and the cities come to live a period, with a constructive rhythm associated to a dissonant musicality. The reason for all of this is that, somehow, globalization has influenced the collective taste of the several peoples, showing and promoting new ways of construction, more ecological and efficient. Cities and buildings become technologically advanced and smart.

Smart cities are organized among themselves and within themselves, communicating and promoting their efficiency. Together the buildings are also becoming more and more intelligent because they are integrated with home technology, controlling and simplifying the life inside and outside of the building itself.

Technological creativity has reached its splendour, actually allowing that technology to be present in our daily lives, although we have not noticed it, but we cannot live without it anymore.

We know that architecture can produce sensations and emotions to the observer, but it was only at the end of the 19th century that this subject began to be addressed, in a more serious way, with the appearance of Robert Vischer's theory of sympathy (Einfulung) (Zevi, 1974). Whoever observes a building will discover a set of emotions that are transmitted through architecture because it manages to emanate states of mind by stimulating and humanizing them by its constructed form.

But if until now architecture was made in favour of Man, there are already many examples where architecture is presented as art appearing in a cold way that ends up being built as a piece of art and not as a construction in benefit of Man as a main element, being understood only as a piece of art and not as a piece of architecture, which triggers the curiosity of Man.

With globalisation people end up travelling faster and faster, so cities are no longer inhabited only by their citizens but also by many foreigners and tourists, the population of towns and cities also increases. The technological advance that is already being revealed through smart cities, has developed a creative spirit in people who are not only citizens but also foreigners and tourists. Technological knowledge becomes widespread and everyone ends up enjoying it without even realising it. Nowadays the city is a kind of machine where we live and inhabit in its interior. All is interconnected and we all have network functions that helps to keep this large machine called city in action. 
Domotics has mechanized the way of living. Now the tasks that were once normal to perform are now carried out by machines, connected to a central computer and to the Internet. For example, today we can open and close the windows in our homes remotely, using a mobile phone and a central computer, which is connected via the Internet. We can turn the air conditioning on and off. Or we can simply leave it programmed so that through sensors, the computer will understand that it is already night and should send an order to turn on the house lights and the heating as well. Anyway, it is a world of opportunities, which happens around us and makes us live in a very different way than we did about 50 years ago. The world has become virtual, and we interact with the real world through the virtual world that surrounds us.

Creativity has also been affected; many people still do not accept the way of being creative at the present time. The continuous necessity of using the Internet to fulfil the most basic functions becomes so dependent from each other that it is impossible to think about not using them.

If on one hand the virtual world, associated with the use of new technologies which help to visualize this virtual world, walks together with the globalization, on the other hand the real world is in a slow defragmentation process of memories and of cultural identity. The cultural values are lost or coexist, strangled by other cultural values that come from globalization.

Our senses, and the way we see the world today, become increasingly organized and disconnected from the historical-cultural reality of each region or of each person (Pallasmaa, 2012).

Technological evolution and globalization began by nullifying reality's senses and imagining them as if in the virtual world those senses were real. In other words, in order to attract more people to a certain event, or to attract more tourists, for example, virtual images were developed, which offers the possibility to travel without moving from home. We can, even before going to a specific place, visualize it and experience it as if we were there. We can experience sensations, through the illusion of virtual reality.

Kotler, Kartajaya, and Setiawan wrote that "Technology allows individuals to express themselves and collaborate with others" (2010, p. 5), and that is what really happens between the video mapping technology and the city, or in this case, the buildings. Citizens can feel it, and in same way they are collaborating with that technology, because they themselves make part from the urban scenario.

We use each time more the sense of vision, and we alienate ourselves of the other senses. With this we become progressively more and more isolated. One of the greatest phenomena of our time is the video mapping, through the projection of large images on the facades of the buildings, we visualize stories, historical events or simply an abstract world of shapes and colours, which make us dream. Creativity is explored at the maximum limit, both by the person who conceives the projections, and by the audience who sees and perceives them in loco.

Video mapping has become not only an entertaining tool, but also a means of communication that can share stories, and help to preserve memories and the cultural identity, making them known through a virtual world that uses the real world as a support. Video mapping brought the possibility to explore the three-dimensionality of the support, that it is the street itself, or simply a building (Moreira Marquez, 2000). 
In other words, we no longer have a distinction between the real world and the virtual world, because with video mapping the two worlds live in perfect harmony.

The city, the streets and the buildings, are all part of that virtual world and can interact with the people, who experience those moments, as if they were part of them too. The city becomes now like a big screen, which offers exclusive possibilities to disseminate knowledge and culture. Attracting more and more citizens and tourists.

The way in which we read the street is directly influenced by the use of technology and with the use of the Internet, becoming a fundamental role in the creative process of architects, who can now design new buildings, thinking about the interaction between the facades and the video mapping, like a skin that dresses the building.

This technology can be manipulated and coordinated from a distance in the context of smart cities and therefore becomes part of the daily life in specific areas of the city, or at certain times not only for playful purposes, but also as an aesthetic and cultural coating of the building space.

In this way a range of aesthetic possibilities are opened up, which will encourage the creativity of architects. Cities become more and more technological and energy efficient, but also more attractive, since they are able to achieve more quickly the goals of spreading sensations and messages through a modern, virtual and high-tech artistic expressions.

The city is often dehumanized due to the fact that the human being becomes a kind of thread, a vehicle for the dissemination of what technology wishes to be achieved. Or, in other words, of what technology does not want to be done. Because if someone behaves out of the imposed rhythm, then the society sees them as outsiders.

The creative process, now, requires a constant multi-sensorial understanding which manipulates the real and the virtual. The creative expression of a modern and smart city turns out to be directly connected with the Internet as a form of creative input, but also as a creative output, since the Internet, besides connecting things and people, is also, on one hand, a vehicle where creativity can drink inspiration and, on the other hand, be a vehicle for the dissemination of events and creative processes in development. Everything works in a network and ends up being disseminated through the Internet. What matters now is what the eyes see and the mind feels.

The cities are no longer silent and calm at night, today the lights and a whole range of advertisements and diverse information are covering the buildings, and the city appears different during the night. The movement of people and the constantly changing lights of colours, the messages that appear on large screens, like movies, no longer seems to affect people's curiosity, since this panoply of information is already part from the DNA of the city.

The inhabitants of cities are not able to perceive the shapes and shadows of buildings (Holl, 2009), it is as if they live not in a city, but in the interior of a computer. Video mapping ends up by stimulating hearing and vision, but it also manages to explore the other senses, since the projections are made in the physical space of the city, where pre-existences are joined to the virtual world. This is not the case when it is just a film or a virtual reality visualization, where the senses that are used by perception are only the visual and the auditive.

The city's culture and memory can now be preserved by using the most modern technologies, such as video mapping. UNESCO has vigorously promoted digital protection intagible 
cultural heritage (ICH). The ICH is the pinnacle of human cultural heritage, and has gradually become an important part of tourism supply (Zhang et al., 2018), heritage is responsible for the identity of a country, it is indeed a kind of national brand, because it represents the characteristics of a certain population and, also, culture sustains the development of the country, as it can attract tourists and stimulate the strategic goals that will be achieved in new business models.

Video mapping can also offer a new way of increased perception and a new experience of seeing the cultural heritage. The huge projections with images, lights and texts using lightemitting diode technology integrates the urban landscape and sets up the basic support for advertising communication (Manovich, 2002).

The urban screens are now part of the daily perception, in other words, the innovation is no longer up to date, but something that has already been turned into a routine and has become part of the city.

Smart cities end up within their tendency to improve the mobility and efficiency of everything that exists and moves within the urban space, including people, ends up promoting the appearance of video mapping, as a technology integrated into their own scenery. In this way, art and artistic expression within the city ends up developing new trends and artistic currents based on the virtual process. The interaction between the buildings and the projections are evident. The video mapping, brings to the outdoor space what until recently was only happening inside closed spaces.

In the book Becoming a Digital Designer (Heller \& Womack, 2008) we can conclude that the authors considered that digital interactivity and the scale of digital projection changed with the technological advance and with the expectations that are increasingly higher and more exigent.

Darley in his book Visual Digital Culture defined that "the aesthetics of the surface", is what is behind these wonderful artistic manifestations related to video mapping in the urban scenario (2006). As Maldonado recalls, Western civilization has become essentially a producer and consumer of trompe-loeil. That is, the virtual has become an assumed part of the real world, and this is one of the first steps that reveal how a smart city, with modern and up-to-date people, accept to interact with the virtual world in an assumedly real way (Maldonado, 2015).

The huge amount of commercial advertising that exists inside of the city creates an enormous amount of visual pollution. Nowadays, in an increasingly digitalized world the advertising has been following this process, and now large screens are spread across the city streets and in the most strategic points, trying to broadcast an up-to-date message and an immediate interaction with the inhabitants. These large screens become more and more visible in relation with other advertising structures.

The video-mapping could influence how advertising will be done in the future. Because video-mapping does not need such large structures and also does not cause a negative impact in terms of visual pollution. A single structure, can have several projectors that project the advertisements in several buildings. With the benefit of easily switching advertising, only by using the Internet and a computer. But let us imagine now, if instead of advertising, new coverings were projected on the facades of buildings? The architecture and the urban environment built, lives of its materiality, but the video-mapping lives of the interception between time and space, between the imaginary and the real (Verhoeff, 2016). 
Cities have always been "smart", because they have always been organized, and even without the use of technology, people have got used to having rules in the cities and had to learn them to survive. Of course, a smart city of today is quite different, because especially in the chapter of urban mobility, the artificial intelligence systems have carried out an organizational revolution, controlling effectively from people, to public transport, or even the waiting time at the traffic lights.

The use of video-mapping has been a more playful feature up to the present time, where in special occasions, performances are organized with projections on the facades of different buildings. These events, besides making local commerce more dynamic, end to attract more and more people who can feel themselves interacting between the urban scene and the virtual projections. Often the images take on a huge scale, so they end up attracting even more people's attention. In a smart city, the use of video mapping can change the way we are all used to seeing the city. Up to now, advertising structures have developed to catch people's attention and therefore the kind of graphic language has changed over the years, following fashions and marketing guidelines, to reach people in a quicker way.

Today we are no longer surprised with screens of large proportions, showing small advertising films, many linked through the Internet, and managed remotely, to control their contents, according to, for example, the car traffic at that time. The effectiveness of videomapping in a smart city is very considerable. For example, in the advertising sector, the message can be passed more quickly to the people, since the image would be tremendously large, and will outperform all other forms of advertising in the city. But it could also have a playful and cultural character. Let us imagine that through video-mapping, it would be possible at some hours, namely in the evening, to virtually visit a museum, or to view an exhibition, which is inside of the building where those same images are being projected. But in reality, where video-mapping can play a very important role, it is precisely in the architecture and the way that buildings could be transformed between the day and the night.

Imagine a street, where buildings during the night would change color, or be covered with a different, virtual, material, or that simply that building would be a big waterfall. Or imagine, now, that you want to create a certain atmosphere that provides a good state of mind, using the right colours and shapes, in order to make people during the night feeling good mood. Let us also imagine, like new buildings, they could adhere to this technology, associate it to home automation and the Internet, and be the owner who decides how they want the building to "dress" during the night. The buildings could have a simple construction, during the day, and become a Baroque building during the night. Verhoeff (2016, p. 129) pointed out, "As soon as lighting technologies are used to modify the visual appearance of a building, the light becomes part of it". The dynamic of the streets, after the use of video-mapping becomes iterative. That is why video-mapping will be an essential tool for the future of smart architecture, as it will be considered nearly on the same level as a surfacing material. The video-mapping, in those buildings, would be linked to an internal automation system, which will be manipulated remotely, or by the owners of the house, or even by the City Hall. Until today, technology inside and outside buildings aims at comfort and sustainability, but it is not very common to use technology to "dress" buildings. That is exactly what video-mapping can do. 


\section{Conclusions}

Nothing stands still in the world of technology, which forces a need for a new look at the management of urban space that is becoming more and more unconventional and exciting. At the same time, the position of technology in that process changes and so does its role in building a smart city value. For a success does not only depend on a number or degree of complexity of adopted solutions, but on a level of mutual convergence between technology and a human. It is the human creativity that determines socially and economically justified potential of a given technology while enabling a human to become an integral part of changes taking place around them. The more smart cities balance in the space of these interactions, the more indispensable element the creativity becomes while being a natural stage of transition to a new perspective of city development.

The city stays the same, where the colours of the buildings, the shapes and the use of technology can coexist. They can even serve to create conditions for new architectural shapes that will include technological equipment. Technologies, like video mapping, have the power to enrich and enhance local heritage and protect the memory of the place, with a modern way of history telling. The creativity associated with arts in general, can give a hand to the economy, offering new and unexpected ways to attract people and tourists to specific places, and it is here that the video mapping can help. A smart and creative city is designed to be a contemporary urban attraction place, converting, step by step, the streets, buildings and citizens activities towards a creative and technological culture and a new daily routine.

\section{References}

Algorithm Watch, Bertelsmann Stiftung. (2019). Automating society: taking stock of automated decision-making in the EU. AW AlgorithmWatch gGmbH.

Anilir, S., Linner, Th., Bener Suay, H., \& Bock, Th. (2009). Application of Infra-Free Motherboard (IF $\left.{ }^{\mathrm{M}}\right)$ in a decentralized community for a customized real-time processing multidirectional energy supply network. Journal of Asian Architecture and Building Engineering, 8(2), 407-414. https://doi.org/10.3130/jaabe.8.407

Bell, S., Benatti, F., Edwards, N. R., Laney, R., Morse, D. R., Piccolo, L., \& Zanetti, O. (2018). Smart cities and $\mathrm{M}^{3}$ : rapid research, meaningful metrics and co-design. Systemic Practice and Action Research, 31, 27-53. https://doi.org/10.1007/s11213-017-9415-x

Bhati, A., Hansen, M., \& Chan, Ch. M. (2017). Energy conservation through smart homes in a smart city: a lesson for Singapore households. Energy Policy, 104, 230-239. https://doi.org/10.1016/j.enpol.2017.01.032

Calderón, M., López, G., \& Marín, G. (2018). Smartness and technical readiness of Latin American cities: a critical assessment. IEEE Access, 6. https://ieeexplore.ieee.org/stamp/stamp. jsp? $\mathrm{tp}=$ \&arnumber $=8485791$

Casile, O. (2011, 6-8 July). IBM, for a smarter planet and smarter cities. Best Student Recognition Event. EMEA IBM Innovation Center. La Gaude, France. file:///C:/Users/Jovile/Downloads/IBM\%20 Smarter\%20Planet\%20\&\%20Smarter\%20Cities.pdf

Chan, Ch.-Sh., \& Marafa, L. M. (2018). Knowledge-perception bridge of green-smart integration of cities: an empirical study of Hong Kong. Sustainability, 10. https://doi.org/10.3390/su10010107

Chen, M., \& Lin, Y. (2019). Exploration and implementation of intelligent park information system 
based on cloud computing and internet of things. International Journal of Online and Biomedical Engineering, 15(1), 115-128. https://doi.org/10.3991/ijoe.v15i01.9783

Cheng, Y.-Ch., Chen, Y.-Ch., Chiang, W.-M., \& Yang, Ch.-L. (2015). Establishing systematic modular courses for key teaching competencies of teachers in Hsinchu City. International Education Studies, 8(5), 21-32. https://doi.org/10.5539/ies.v8n5p21

Contreras Pinochet, L. H., Furtani Romani, G., Souza, de C. A., \& Rodríguez-Abitia, G. (2019). Intention to live in a Smart City based on its characteristics in the perception by the Young Public. Revista de Gestão, 26(1), 73-92. https://doi.org/10.1108/REGE-06-2018-0077

D’Aniello, G., Gaeta, M., Loia, F., Reformat, M., \& Toti, D. (2018). An environment for collective perception based on fuzzy and semantic approaches. Journal of Artificial Intelligence and Soft Computing Research, 8(3), 191-210. https://doi.org/10.1515/jaiscr-2018-0013

Darley, A. (2006). Videoculture digitali. Spettacolo e giochi di superficie nei nuovi media. Franco Angeli.

Dosi, G. (2000). Innovation, organization and economic dynamics: selected essays. Edward Elgar Publishing.

Du, J., Kuang, B., \& Yang, Y. (2019). A data-driven framework for smart urban domestic wastewater: a sustainability perspective. Hindawi: Advances in Civil Engineering. http://downloads.hindawi.com/ journals/ace/2019/6530626.pdf

Ek, A., Alexandrou, Ch., Delisle Nyström, Ch., Direito, A., Eriksson, U., Hammar, U., Henriksson, P., Maddison, R., Trolle Lagerros, Y., \& Löf, M. (2018). The Smart City Active Mobile Phone Intervention (SCAMPI) study to promote physical activity through active transportation in healthy adults: a study protocol for a randomised controlled trial. BMC Public Health, 18. https://bmcpublichealth. biomedcentral.com/track/pdf/10.1186/s12889-018-5658-4

Guidehouse Insights. (2019). Smart City Tracker 2Q19: Global Smart City Projects by world region, market segment, technology, and application. https://guidehouseinsights.com/reports/smart-citytracker-2q19

Heller, S., \& Womack, D. (2008). Become a digital designer: a guide to careers in web, video, broadcast, game, and animation design. John Wiley \& Sons.

Hemalata, V., Saraswathy Shamini, G., \& Sumathi, B. (2019). Smart City: the state of the art, definitions, characteristics and dimensions. Journal of Computational and Theoretical Nanoscience, 16(8), 3525-3531. https://doi.org/10.1166/jctn.2019.8318

Holl, S. (2009). Urbanisms: working with doubt. Princeton Architectural Press.

Holl, S., Pallasmaa, J., \& Pérez-Gómez, A. (Eds.). (2006). Question of perception: phenomenology of architecture. $\mathrm{a}+\mathrm{u}$ Publishing Co., Ltd./William Stout Publishers.

James, A., \& Nagasaka, D. (2011). Theoretical connection points between multimedia and architecture. Journal of Asian Architecture and Building Engineering, 10(1), 171-178. https://doi.org/10.3130/jaabe.10.171

Kang, J., Aletta, F., Margaritis, E., \& Yang, M. (2018). A model for implementing soundscape maps in Smart Cities. Noise Mapping, 5, 46-59. https://doi.org/10.1515/noise-2018-0004

Kim, M. J., Cho, M. E., \& Chae, H. H. (2014). A smart community for placemaking in housing complexes. Journal of Asian Architecture and Building Engineering, 13(3), 539-546. https://doi.org/10.3130/jaabe.13.539

Komninos, N., \& Kakderi, Ch. (Eds.). (2019). Smart Cities in the post-algorithmic era: integrating technologies, platforms and governance. Series: Cities Series. J. R. Short (Series Ed.). Edward Elgar Publishing. https://doi.org/10.4337/9781789907056

Kotler, Ph., Kartajaya, H., \& Setiawan, I. (2010). Marketing 3.0: from products to customers to the human spirit. John Wiley \& Sons, Inc. https://doi.org/10.1002/9781118257883

Kunzmann, K. R. (2014). Smart Cities: a new paradigm of urban development. Crios, 1, 9-20. 
Lee, J.-H., \& Lee, W.-J. (2013). A study on the impact of ubiquitous street furniture on human behavior - based on media poles installed on Seoul's Gangnam Boulevard. Journal of Asian Architecture and Building Engineering, 12(2), 181-188. https://doi.org/10.3130/jaabe.12.181

Leone, G. R., Moroni, D., Pieri, G., Petracca, M., Salvetti, O., Azzarà, A., \& Marino, F. (2017). An intelligent cooperative visual sensor network for urban mobility. Sensors, 17. https://www.mdpi. com/1424-8220/17/11/2588

Li, F., \& Zheng, B. (2016). Design of the smart city planning system based on the internet of things. International Journal of Smart Home, 10(11), 207-218. https://doi.org/10.14257/ijsh.2016.10.11.18

Lytras, M. D., Visvizi, A., \& Sarirete, A. (2019). Clustering Smart City services: perceptions, expectations, responses. Sustainability, 11. https://www.mdpi.com/2071-1050/11/6/1669

Macke, J., Casagrande, R. M., Sarate, J. A. R., \& Silva, K. A. (2018). Smart City and quality of life: citizens' perception in a Brazilian case study. Journal of Cleaner Production, 182, 717-726.

https://doi.org/10.1016/j.jclepro.2018.02.078

Maldonado, T. (2015). Reale e virtuale. Giangiacomo Feltrinelli Editore Milano.

Manovich, L. (2002). Il linguaggio dei nuovi media. Olivares.

Mattern, Sh. (2017). A city is not a computer. Places. https://placesjournal.org/article/a-city-is-not-acomputer/?cn-reloaded $=1$

McKinsey Global Institute. (2018). Smart Cities: digital solutions for a more livable future. McKinsey \& Company. https:/www.mckinsey.com/industries/capital-projects-and-infrastructure/our-insights/ smart-cities-digital-solutions-for-a-more-livable-future

Meijer, A., \& Rodríguez Bolívar, M. P. (2015). Governing the Smart City: a review of the literature on smart urban governance. International Review of Administrative Sciences, 82(2), 392-408. https://doi.org/10.1177/0020852314564308

Milošević, M. R., Milošević, D. M., Stević, D. M., \& Stanojević, A. D. (2019). Smart City: modeling key indicators in Serbia Using IT2FS. Sustainability, 11. https://www.mdpi.com/2071-1050/11/13/3536/ notes

Monzon, A. (2016). Smart Cities concept and challenges: bases for the assessment of Smart City projects. https://ieeexplore.ieee.org/stamp/stamp.jsp?tp=\&arnumber=7297938

Moreira Marquez, R. (2000). Cidades em instalação: arte contemporânea no espaço urbano (Doctoral/ PhD Thesis). Escola de Arquitetura da UFMG.

Moura, F., \& Abreu e Silva, de J. (2019). Smart cities: definitions, evolution of the concept and examples of initiatives. In W. Leal Filho, A. Azul, L. Brandli, P. Özuyar, \& T. Wall (Eds.), Industry, innovation and infrastructure (pp. 1-9). Series: Encyclopedia of the UN Sustainable Development Goals. Springer Nature Switzerland AG. https://doi.org/10.1007/978-3-319-71059-4_6-1

Muhajarine, N., Katapally, T. R., Fuller, D., Stanley, K. G., \& Rainham, D. (2015). Longitudinal active living research to address physical inactivity and sedentary behaviour in children in transition from preadolescence to adolescence. BMC Public Health, 15. https://bmcpublichealth.biomedcentral.com/track/pdf/10.1186/s12889-015-1822-2

Mulder, I. (2014, 22-27 June). Sociable Smart Cities: rethinking our future through co-creative partnerships. In N. Streitz \& P. Markopoulos (Eds.), Distributed, Ambient, and Pervasive Interactions: Proceedings of 2nd International Conference, DAPI 2014, Held as Part of HCI International 2014. 2nd International Conference, DAPI 2014, Held as Part of HCI International 2014 (pp. 566-574). Heraklion, Crete, Greece. Springer International Publishing. https://doi.org/10.1007/978-3-319-07788-8_52

Mumford, L. (1937). What is a city? Architectural Record. https://cityasynthesis.files.wordpress. com/2012/09/mumford-what-is-a-city-1937.pdf

Musatova, Zh., Mhitaryan, S., Nevostruev, P., Sidorchuk, R., \& Komleva, N. (2016). Smart-technolo- 
gies in public transport and their perception by the youth audience. Indian Journal of Science and Technology, 9(42), 164-167. https://doi.org/10.17485/ijst/2016/v9i42/104278

Nam, T., \& Pardo, Th. A. (2011, June). Conceptualizing smart city with dimensions of technology, people, and institutions. The Proceedings of the 12th Annual International Conference on Digital Government Research: Digital Government Innovation in Challenging Times. 2011 12th Annual International Conference on Digital Government Research: Digital Government Innovation in Challenging Times (pp. 282-291). College Park Maryland, United States. https://doi.org/10.1145/2037556.2037602

Niaros, V. (2016). Introducing a taxonomy of the "Smart City": towards a commons-oriented approach? TripleC: Journal for a Global Sustainable Information Society, 14(1), 51-61. https://doi.org/10.31269/triplec.v14i1.718

Niculescu-Dincă, V. (2018). Towards a sedimentology of information infrastructures: a geological approach for understanding the city. Philosophy and Technology, 31, 455-472. https://doi.org/10.1007/s13347-017-0298-7

Pallasmaa, J. (2012). The eyes of the skin: architecture and the senses. John Wiley \& Sons Ltd.

Pan, W., \& Cheng, G. (2018). QoE assessment of encrypted YouTube adaptive streaming for energy saving in Smart Cities. IEEE Access, 6. https://ieeexplore.ieee.org/stamp/stamp. jsp?tp=\&arnumber $=8310894$

Pérez, S., Laperrière, V., Borderon, M., Padilla, C., Maignant, G., \& Oliveau, S. (2016). Evolution of research in health geographics through the International Journal of Health Geographics (20022015). International Journal of Health Geographics, 15(3). https://ij-healthgeographics.biomedcentral.com/track/pdf/10.1186/s12942-016-0032-1

Rabazauskaite, V. (2015). Revitalisation of public spaces in the context of creative tourism. Creativity Studies, 8(2), 124-133. https://doi.org/10.3846/23450479.2015.1053543

Reardon, M. (2016). Three generations of smart cities. IBI Group. https://www.ibigroup.com/ibi-ideas/ three-generations-of-smart-cities/

Reddy Kummitha, R. K., \& Crutzen, N. (2017). How do we understand smart cities? An evolutionary perspective. Cities, 67, 43-52. https://doi.org/10.1016/j.cities.2017.04.010

Ruutu, S., Casey, Th., \& Kotovirta, V. (2017). Development and competition of digital service platforms: a system dynamics approach. Technological Forecasting and Social Change, 117, 119-130. https://doi.org/10.1016/j.techfore.2016.12.011

Sánchez-Teba, E. M., \& Bermúdez-González, G. J. (2019). Are Smart-City projects citizen-centered? Social Sciences, 8. https://www.mdpi.com/2076-0760/8/11/309

Si Min Lim, H., \& Taeihagh, A. (2019). Algorithmic decision-making in avs: understanding ethical and technical concerns for Smart Cities. Sustainability, 11. https://www.mdpi.com/2071$1050 / 11 / 20 / 5791$

Stanković, J., Džunić, M., Džunić, Ž., \& Marinković, S. (2017). A multi-criteria evaluation of the European Cities' smart performance: economic, social and environmental aspects. Journal of Economics and Business, 35(2), 519-550. https://doi.org/10.18045/zbefri.2017.2.519

Suryanegara, M., Agung Prasetyo, D., Andriyanto, F., \& Hayati, N. (2019). A 5-Step framework for measuring the Quality of Experience (QoE) of Internet of Things (IoT) services. IEEE Access, 7. https://ieeexplore.ieee.org/stamp/stamp.jsp?tp=\&arnumber $=8922616$

Tunzelmann, von N., Malerba, F., Nightingale, P., \& Metcalfe, S. (2008). Technological paradigms: past, present and future. Industrial and Corporate Change, 17(3), 467-484.

https://doi.org/10.1093/icc/dtn012

Uzzell, D. (2008). People-environment relationships in a digital world. Journal of Architectural and Planning Research, 25(2), 94-105. 
Verhoeff, N. (2016). Screens in the City. In D. Chateau \& J. Moure (Eds.). Screens: from materiality to spectatorship - a historical and theoretical reassessment (pp. 125-139). Amsterdam University Press. https://doi.org/10.1515/9789048531691-013

Wirth, L. (1938). Urbanism as a way of life. American Journal of Sociology, 44(1), 1-24. https://doi.org/10.1086/217913

Wuebben, J. (2017). Future marketing: winning in the prosumer age. Content Launch Press.

Yang, B. (2019). Developing a Mobile Mapping System for 3D GIS and Smart City planning. Sustainability, 11. https://www.mdpi.com/2071-1050/11/13/3713

Zandbergen, A. D. (2011). The Dawn of the Age of the Homo Cyber. https://openaccess.leidenuniv.nl/ bitstream/handle/1887/17671/introduction.pdf? sequence $=4$

Zevi, B. (1974). Architecture as space: how to look at architecture. Horizon Press.

Zhang, Y., Han, M., \& Chen, W. (2018). The strategy of digital scenic area planning from the perspective of intangible cultural heritage protection. EURASIP Journal on Image and Video Processing. https:// link.springer.com/content/pdf/10.1186/s13640-018-0366-7.pdf

\section{AR IŠMANUSIS MIESTAS - KŪRYBIŠKA VIETA? \\ Emilian GWIAŹDZIŃSKI, Dominika KACZOROWSKA-SPYCHALSKA,
Luís MOREIRA PINTO}

Santrauka

Šiame straipsnyje skelbiame tyrimus, susijusius su miesto kūrybiškumo sritimi, daugiausia demesio skirdami tam, kaip išmanieji miestai vis labiau ir labiau tampa savarankiškesni ir kuria tvaraus autonomiškumo dvasią, kuri tam tikru būdu lemia kūrybinių galimybių atsiradimą atminties ir kultūrinio tapatumo prasme. Šiame straipsnyje keliamas klausimas - kaip išmanieji miestai gali paveikti kūrybinị procesą? Manome, kad kūrybiškumas tampa procesu, susijusiu su skaitmeniniu pasauliu, ir darosi kur kas interaktyvesnis. Štai kodèl naujus meninès ir skaitmeninès išraiškos būdus palankiai priima tie, kurie yra ịpratę prie naujųjų technologijų, o šios kasdien daro įtaką žmogaus aktyvumui miesto erdveje. Kitaip tariant, naudojantis turimomis technologijomis miestuose ir pajungiant jų tarpusavio ryšius su kitais miestais, kūrybines strategijas galima suvokti kaip tai, kas padès išsaugoti žmonių atmintị, taip pat jų kultūrinị ir kūrybinį tapatumą. Vaizdo žemèlapių sudarymas yra viena iš tų kūrybinių strategijų, kuri sukurs tiesioginę realumo ir virtualumo dimensijų sąveiką. Vaizdo žemèlapiai kaip elementas, paslepiantis pastatų fasadus, tam tikru būdu gali padèti gatvèms tapti dinamiškesnèms ir paversti jas kita aplinka. Miestas tampa trečiosios dimesnsijos dalimi, o žmonès sąveikauja tarp to, kas yra realu, ir to, kas virtualu. Miesto erdvès valdymas pamažu kinta, atsižvelgiant ị technologinę pažangą. Mobilumas ir tvarumas - vieni pagrindinių veiksnių, ị kuriuos išmanusis miestas investavo daugiausia. Dabar yra metas investuoti ị miesto ir žmonių santykị, paverčiant ji žmogiškesniu ir suteikiant erdvès kūrybiškumui.

Reikšminiai žodžiai: kūrybinis miestas, skaitmeninès technologijos, žmogus, informacijos ir komunikacijos technologijos, valdymas, išmanusis miestas. 